\title{
Surge of Divorce in Lahore, its Exploring Factors and Possible Solutions, Pakistan
}

\author{
Shahid Qayyum Khaleek \\ khaleekgee@gmail.com
}

\begin{abstract}
Abid Hussain
Abstract

The study had been documented in Lahore city. The objectives of the study were to find factors of divorce and possible solutions to minimize the surge of divorce. The present study was qualitative in nature. For covering all the objectives comprehensively, there were forty two participants in total figure including both the genders and taken form three different segments of the population like divorced people selected using snowball sampling technique, lawyers were accessed using convenient sampling technique and married people were also approached who conveniently available at the time of data collection. An unstructured check list was prepared to collect the information with regard to study objectives. In view of findings, results demonstrate there was no single factor leads to divorce but many like economic instability, greed of dowry and wealth, unemployment, disparity in education, joint family system, exchange marriages, early age marriages, birth of girl child, dual marriages, disparity in social status, external pressures, forced and pressurized marriages, spousal illegal relationships, unrealistic expectations, fraud in marriages ,drug abusing, age incompatibility, mental incompatibility, infertility, short-temperament or patience, lack of compromises or sacrifices, egoistical issues. In lieu of effects, divorce left many heinous psychological, social, economic effects on both the gender victims which may further become the cause in personality disorder. With regard to solutions which may be impediments in breaking the legal agreement between male and female like compromise and sacrifices, patience and endurance, empathetic way of analysis, develop feeling of "We" not " $I$ ", respect and honor, caring in every matter of life, no space for lie or mistrust, freedom of speech, egalitarian approach in decision making, sharing gifts and pleasures, caring about liking and disliking, pardon on mistakes, respect for family and relatives not by one part but from both the sides.
\end{abstract}

Key Words: Divorce, Factors, Solutions

\section{INTRODUCTION}

Marriage is the formal union of people between a man and a lady, regularly as perceived by law by which they get to be spouse and wife. Marriage is an exceptionally consecrated commitment and it is honed practically by every religion, society, society and nation. It is not only a relationship between a kid and a young lady yet it is the union of two separate families. Separation is disintegration of marriage or end of a conjugal union between wedded couples under the standard of law of the specific nation. Individuals get hitched for adoration, sexual needs, security, youngsters, cash, life accomplice and so forth while oppositely get separated likely and just about for the same reasons. All the tussles might be settled with trading off procedures however at some point there are circumstances in which separate is the main alternative. Separation is something that is scorned by ALLAH however it is permitted on the grounds that there are circumstances where separation is stayed just and just reply. As ALLAH says, 
"And if you fear that the two (husband and wife) may not be able to keep the limits orderd by allah, there is no blame on either of them if she redeems herself"

Friedrich Nietzsche stated that "it is not a lack of love, but a lack of friendship that makes unhappy marriages"

Friendship is fundamental in every relationship whether it is a relationship of father, mother, spouse or wife. Kinship is a sort of relationship in which one feels calm to impart everything. At the point when this component is eradicated in the relationship of marriage, debate may emerge. Marriage is the other name of bargaining. Both spouse and wife need to bargain on everything. In the event that one gets neglected to trade off than the result is winding up of relationship.

Divorce is an issue in Pakistani society as well as entire the world. In Pakistan the separation proportion has gone up to a disturbing degree from a decade ago. As Pakistan is a traditional nation so the saying "separation" is considered as the image of disgrace and embarrassment. An advocate Chaudhary Shoaib said in the past the expression separation was an unthinkable in Pakistani society, yet now individuals don't feel embarrassed of getting separation.

The separation rate has been on the ascent in Pakistan in the course of the most recent decade. In Lahore city alone, more than 120 separations are enlisted in family courts in a day. The separation rate is expanding in the privileged of society as well as in lower and white collar classes. A senior attorney Mr. Irfan Gujjar said the separation rate is higher among taught families. Prof. Dr. Marriam Malik said Indian and western social attack is exasperating the circumstances. He said females who stare at the TV channels need to purchase expensive things at all expense, now and again at the cost of their marriage. He said spouses' sense of self additionally had a part in an expanding number of separations. He said separated couple's youngsters carry on with a horrible life and hence folks ought to need to understand that they have an obligation towards their kids. Marriage is a huge choice in one's life, and ought to be taken, just when one is develop enough to handle all that accompanies it. Constrained relational unions and early relational unions are a reality in Pakistan and need to be halted," he said.

From February 2008 to January 2011 give or take 75, 000 separation cases had been enrolled. From February 2011 to May 2013, 1, 24141 separation cases were enlisted. Around 2, 59064 partitions have occurred in the commonplace city throughout the most recent decade. In 2014, 40,410 detachment cases were enrolled in the city's family courts and 13,500" separations have been recorded so far in 2014. Separation was expanding generally among couples between ages 22 and 30 .

In excess of 2,300 ladies have approached courts in recent months for disintegration of marriage. The authority information issued by Districts Courts Lahore revealed that more than 11,000 cases identified with family issues were pending in the courts, a large portion of which were of separation and disintegration of relational unions, which implies that the normal transfer of cases has arrived at 336.67 for every day. Around 150 separation cases are recorded day by day by ladies. More than 2300 ladies expected to courts for disintegration of marriage. Around 75 percent of uses are moved for disintegration of marriage while other 25 percent are documented identified with support charges, said the sources. 
A review showed 300 cases out of 12,000, pending before family courts of the city, explored that 7.8 percent ladies of Gulberg, DHA and Model Town (Gulberg 3 percent, DHA 2.2 percent, Bund Road alone has 8 percent and Model Town 2.6 percent) moved the courts for disintegration of relational unions. Around 32.7 percent ladies of less special zones have moved the courts to purpose their separation debate. 7.1 percent ladies in Cantonment requested conjugal rights through courts from their previous spouses, the study uncovers. The Cantonment incorporates Saddar, Burki, and Manawan. Ladies of Shalamar and its suburbs (7.5 percent), Shahdara (7.2 percent), Multan Road (3.4 percent), Wahdat Colony (0.75 percent), Johar Town/Iqbal Town (3.4 percent) and Chungi Amarsidhu (1.5 percent) took their family question before the courts.

Advocate Surayya Farzand Chaudhry, who advocates family cases, said, "If a matter occurs in a fortunate family, it is determined through placation and in few cases separation happens. On the off chance that a question raises in a less advantaged family, the spouse beats the wife and powers her to leave home. In such cases, spouses not, one or the other let their wives return home, nor separation them, which constrain the ladies to approach the courts." She said, "In a few cases, the spouse separates his wife, yet does not give back her dower, which again heads the ladies to move the courts."

\title{
Objectives:
}

○ To find the causes of increasing divorce rate

○ To draw the solutions of minimizing divorce rate

\begin{abstract}
MATERIAL AND METHODS
In concern of research methodology, the study was conducted in Lahore city and by nature it was qualitative. The objectives of the study were to explore the factors of divorce and find possible solutions to minimize the surge of divorce. The sample size was consisted of 42 participants with equal proportion in view of gender. In the study, there were three different segments of the population were approached to explore all possible factors and draw its solutions. In first segment, fourteen divorced both genders equally were apprehended to fulfill the objectives of the study through snow-ball sampling technique. In second segment, fourteen lawyers both male and female with equal proportion had been accessed using convenient sampling technique to get the manifestos of the study, taking analogy lawyers dealing all these issues of their clients in courts and may good source in view of study objectives. In third and last segment, fourteen married people of both the genders with equal proportion were approached applying convenient sampling technique to achieve the third objective of the study. A check list had been used for the collection of the data respectively and data was analyzed in descriptive and explanatory way of methods.
\end{abstract}


RESULTS AND DISCUSSION

Table No. 01 Socio-status Characteristics of the participants

\begin{tabular}{ccc}
\hline Variables & Frequency & Percentage (\%) \\
Gender & 21 & \\
Male & 21 & 50.0 \\
Female & & 50.0 \\
\hline Age (Years) & 03 & \\
$25-30$ & 05 & 7.14 \\
$31-35$ & 21 & 11.90 \\
$36-40$ & 13 & 50.0 \\
41 and Above & & 30.95 \\
\hline Education & 09 & \\
Intermediate & 06 & 21.42 \\
Graduation & 26 & 14.28 \\
Masters & 01 & 61.90 \\
Above Masters & & 02.38 \\
Marital Status & 14 & 33.33 \\
Married & 14 & 33.33 \\
Divorced & & \\
Professional Status & 05 & 11.90 \\
Businessman & 14 & 33.33 \\
Lawyer & 08 & 19.04 \\
Govt. Employee & 04 & 09.52 \\
Laborers & 08 & 19.04 \\
Unemployed & 03 & 07.14 \\
Others & $\mathbf{4 2}$ & $\mathbf{1 0 0}$ \\
\hline Total Participants &
\end{tabular}

Table No. 01 demonstrates the socio-status characteristics of the participants on different variables respectively. In concern of gender variable, both were equally approached, 21 male and 21 female in total sample. In lieu of age variable, 03 participants fell in 25-30 years of age category, 05 respondents were in 31-35 category, 21 participants were come under 36-40 years of age category while 13 respondents fell in 41 and above years of age category. With regard of educational background of the participants, 09 respondents secured intermediate degrees, 06 participants had done graduation degree, most of the participants did master degree while rest of 01 participant had possessed above master educational degree. In view of marital status of the participants, 14 respondents were approached from married segment and 14 were accessed from divorced segment of the population at the time of data collection. With reference to professional status of the participants, 05 respondents secured their own business, most of the 14 respondents were professional lawyer among the total sample, 08 participants were Govt. employee, 04 were from laborers segment while 08 participants were from unemployed segment of the population and 03 respondents belonged to some other professions.

\section{FACTORS OF INCREASING DIVORCE RATE}

There were many factors found involving in increasing the divorce rate among new married segment in Lahore. In reference to that factors were categories and explained keeping them in hierarchal order that following respectively:

\section{Financial Instability}

Now, in modern era, economy is vital and important indicator for the survival in the society. Everything depends upon money even relationships as well measure in the scale of cost and benefit viewpoint. Financial instability means no proper source of earning or money and anonymity for next eating time. Most of the lawyers, divorced people and married respondents 
indicated the basic reason of divorce is economic instability at ll. So it can be said that stability in financial matters is key to survival in every matter of life and relationships.

\section{Greed of Dowry and Wealth}

In view of economic perspective, greed of dowry and demanding of wealth is another factor by the male segment which put pressures on spouse to get separated instead fulfilling greedy desires. According to lawyers' exposures, there were most of the cases related to dowry and wealth desires. So it can be said that human greed is not end but for happy life, need to be moderate.

\section{Unemployment}

Unemployment refers to people who have not still any earning source and looking for a job or livelihood for survival. It is also a factor that leads to spoils legal relations between couples. Unemployment rate in Pakistan is 6.0 percent (Statistics of Bureau, 2014). In view of respondents' answers, unemployment may be motivating factor towards divorce because without money survival is not possible any more.

\section{Disparity in Education}

Disparity in education means difference in educational background/degrees. A couple who are married but had difference in educational background that may not develop mutual understanding between each other because mentality of both genders differs from each other. If someone is inferior to other in education then may not able to get other's psychology and needs properly. When there is no mutual understanding, there is no mutual relation which may lose the importance of the person which direct link to divorce.

\section{Joint Family System}

Joint family system means a type of extended family may comprised of parents, their children and children's spouses and off springs in one household, under one member's authority. Most of the divorced and married participants gave their opinion that joint family system was also a factor of divorce. They said in joint family system a wife had to face all members differently and it's much tough to adjust in big family. With spending time issues were created by all members who couldn't be compensable even by husband as well.

\section{Exchange Marriages}

Exchange marriage refers to a form of marriage involves a reciprocal exchange of spouses between two nations, groups, tribes, or families. Exchange marriages are factor of divorce. One of participant was divorced just because exchange marriage. She explained no doubt issues in every house but these issues become hurdle without any reason in one's happy life just because exchange marriage. If there is problem in one house, second house automatically suffers and sometimes little issues become big problems that lead to end on divorce from both sides.

\section{Early Age Marriages}

Early marriage refers to any marriage before the legal age of marriage which may 18 years of age for male and female in Pakistan. Early marriages are also a factor of divorce according to the participants. In early marriage, girl or male are not so mature to bear their responsibilities effectively. If there is early marriage, definitely there are worries and issues for the both genders. Marriage must be done when maturity comes not in puberty age that may it harmful at all. 


\section{Birth of Girl Child}

Only birth of girl child by the female becomes cause of divorce when there is demanded a boy baby. Many incidents had been occurred in which female were divorced, threatened, flamed, etc. just because they were unable to give birth boy baby. It's considered the fault by female whether it's by male which is scientifically approved. Female has XX sperm while male occupies $\mathrm{XY}$. If $\mathrm{X}$ by male match to $\mathrm{X}$ of female than there would be boy baby and when $\mathrm{Y}$ by male match to $\mathrm{X}$ of female then there would be girl baby. It can be said that scientifically its fault in male not in female.

\section{Dual Marriages}

Dual marriage means someone's doing another marriage in spite of having one as well in legal relations. The practice or custom of having more than one wife or husband at the same time is called polygamy in sociology. Pakistan is Islamic country and with reference to Islam, a male can have four wives in legal relations at one time but if he is able to afford all needs of both. Now, in modern era, doing dual marriage in spite of having one is considered sin. It's not bearable by female that her husband is doing second marriage with her presence and if it is done by male, the first marriage going to end on divorce.

\section{Disparity in Social Status}

Disparity in social status means not equality in social status like differences on the bases of economy, prestige, cast, job, education, wealth, etc. marriage is the name of legal relationship between a male and female in which both bind together in one unit. In one unit both spends life in egalitarian decision system. But when there is difference social status then may arise issues and conflicts there. One who is superior in social status may seduce one's spouse in every matter of life that leads to inferiority complex. When there is the situation, unity can't be exist there which with the passage of time end on divorce according to the participants view point.

\section{Forced and Pressurized Marriages}

Forced and pressurized marriages refer to marriages that had been done against the will of male or female and just because the sake of family's dignity and respect. If there is no mutual will and understanding between both couples, there would be no strong relations between male and female. Forced or pressurized marriages create depression, anxiety and dissatisfaction among both spouses which leads to end on divorce.

\section{Spousal Illegal Relationships}

Spousal illegal relations means developing relations by male/female that is prohibited by law with others is also a factor of divorce. These actions leads to mistrust between both and at end become the cause of spoiling all mutual relations. When one of spouses has illegal or cohabitual relations with illegal peoples, there greater chances of conflicts between both the married couple and sometimes these conflicts create much greater and worse circumstances that would not be controllable and going to ultimately end on divorce.

\section{Unrealistic Expectations}

Unrealistic expectations mean before marriage setting very high standards from both genders and make things beautiful in unreal situations. Manipulate life in beautiful manners and show oneself as there is nothing issue or problem in the after marriage life. From both sides, expectations set very highly. But when after marriage both spouses come into real life and in real situations, things wouldn't as before mention and expectations, set standards break there which generate aggression and separation attitude towards other spouse and all things go to dead on divorce. 


\section{Fraud in Marriages}

Fraud in marriages refers to marriages that are on the bases of fraud and deception. It's new trend emerging in metropolitan cities where people manipulate one self's personality but everything to set and engage oneself with elite class family. For that purpose, houses vehicles, cars, persons, families, parents, suits and many things may get on rent to trap. After doing all procedures, marriage is done than starting a new phase where nothing is real but fraud. In that situation, parents are being blackmailed for money or property. So far marriages on fraud are finished on divorce deliberately.

\section{Drug Abusing}

Drug abusing means habit of taking drugs and it's normally by males in married life. Drug abusing makes man lose-hearted and unstable in every matter of life. Drug abusing makes man blind from one's responsibilities and in that situation no one has importance but drugs. Doesn't matter what is happening in addicted person's life whether losing job, family but not compromising on drugs. When there is addiction of drugs then no space for any relations. In view of that most of the marriages destroyed due to drug abusing.

\section{Age Incompatibility}

Age incompatibility means difference in age between married couples. It's the factor considered in divorce. The difference in age may be impediment in understanding each other's needs and psychology. In looking, it's not suit the age difference between spouses. May other factors having major or vital paly in divorce but some extent age incompatibility is also contributing indicator in divorce. Analogy, many more factors involve for someone to take decision of divorce like that in view of analogy, age incompatibility is the factor as well of divorce between couples.

\section{Infertility}

Infertility is a term which is broadly used in population sciences and refers to inability of a woman to perceive sperm and give birth to a child. Infertility is a very significant cause of divorce because almost every couple wants to get their own children but when the situation of infertility, male segment thinking about second marriage and its mostly unbearable for first wife that inspires her to get divorce.

\section{Short-temperament or Patience}

Short-term temperament means inability to listen and bear things by the male/female. No doubt, may issues and little conflicts exist in every person and every couple but all are resolvable between both. But if these little issues get egoistic status, there is no way to resolve the issues any more. Absence of patience makes issues confused and complicated that further gives way to divorce. It can be said that may it little but important factor of divorce which about ought to be careful.

\section{Lack of Compromises or Sacrifices}

Lack of compromises and sacrifices are very strong and significant causes of divorce. When there is no compromise on different things and matters, there is absolute possibility of not developing mutual and efficient relationships between married spouses. It's usually by female segment. When only demands by the female for different thing in spite of ignoring the status and position of her husband then there is possibility of ignoring one's wife which make relations weak with the passage of time. Sometimes these factors become the cause of divorce. 


\section{POSSIBLE SOLUTIONS AVOIDING DIVORCE}

In lieu of some solutions to save couples from divorce indicating by the participants here explained bellow following:

\section{Compromise and Sacrifices}

In view of the opinion of the participants, compromise and sacrifices is the best key to save the relations in every stage and situation. Try best to compromise and sacrifice on your wills to make happy your companion and better situations.

\section{Patience and Endurance}

Another factor which may much helpful in avoiding from divorce is patience and endurance. According to the perspective of the participants, patience and endurance are the silent behavior for both the spouses to make happy life. They said if both have patience and endurance attitude in every matter of issue than everything going on track which strengthens the relationships in loving manners because both need help each other to stand with each other as wall before worries, issues and problems but everything.

\section{Empathetic way of Analysis}

Empathetic means to see the things, worries, issues, and problems with suffering's eyes and situations. If both spouses have empathetic attitude towards each other then there would be no way of clash and conflicts between couples. Understanding to each other is the significant indicator to develop loving relationships at all.

\section{Develop feeling of "WE" not "I"}

With the perceptions of the respondents, developing feelings of "We" for each other is also best factor in developing love instead promoting feeling of "I". When both the couples have "we" feelings for each other than no issue, worry, tension, problem stands before them ever and this factor enhance the loving attitude towards each other.

\section{Respect and Honor}

Respect and honor is need of everyone everywhere. Pakistani society is male dominant society where necessary for a wife to obey her husband in every matter of life for get respect from the society and her husband. A woman is considered wise and intellectual who is more caring, respectful, and obeying to her husband in his wills at all. Obliviously, respect for each other is essential element for both genders to enhance love and caring between each other. Simply it can be said that respect is key to love.

\section{Caring in every matter of Life}

Caring means having so strong loving feelings towards one's life in every matter. For enhancing and developing love, it's golden rule to be so caring for one's husband/wife like to be so careful about little things which creates happiness or sadness. To feel one's companion I'm here for you and only for you in every situation that may enhance love between both the genders like make yourself according to the likeness of one's companion.

\section{No space for lie or Mistrust}

There is no any space of lie or mistrust in any relation if there is need of good relations. Having trust is like a diamond and if once diamond breaks never ever gets back in real condition. Like that example if once trust breaks, never ever develops twice. Mistrust starts from lie which further leads to make the whole in good relations which cannot be filled again. So, it's golden rule for loving relations not give any space to lie or mistrust in married relations ever. 


\section{Freedom of Speech}

Freedom of speech refers to autonomy and freedom in say something in life matters. According to the perceptions of the participants having not freedom of speech for wife in decisional matters is also a factor which lowers the caring and loving feelings for her husband. So, it may beneficial to give freedom of speech to wife in making enough loving space in your wife's heart.

\section{Egalitarian Approach in Decision Making}

Egalitarian refers to equal rights or opportunities for both genders in decision making for every matter of life. In view of that egalitarian approach must be implemented in married life in every matter of life so that wife may feel your companion and may stand with you in every circumstance and situation.

\section{Sharing Gifts and Pleasures}

Sharing gifts and exchange pleasures refer to care one's special dates, events, occasions and sharing gifts, emotions, feelings with one's companion. This attitude develops love up to the peak level. Like sharing gifts is that would be the most favorable in loving relations on birthday, anniversary or on some special event and give way to perceive one's feelings and emotions.

\section{Pardon on Mistakes}

It is reality "error is in human nature" and on the other side human is the best creation of God. God has created the entire things for human. For good relations, its golden rule to pardon on mistakes because human learned from mistakes and ultimately reality in in mistakes. Like that its necessary rule for implementation in married life between husband and wife.

\section{Respect for Family and Relatives}

Respect for family and relatives are need of time. Pakistani society is male dominant society where necessary for a wife to obey her husband and his family to get respect from the society and her husband. A woman is considered wise and intellectual who is more caring, respectful, and obeying to her husband and his family at all. Obliviously, respect for each other is essential element for both genders to enhance love and caring between each other. Simply it can be said that respect is key to love.

\section{CONCLUSION}

At finally, study found different factors which may possibly involve in breaking the legal agreements and relations between male and female. With regard to findings, results demonstrate there was no single factor involves and leads to divorce but many that may from both sides like economic instability, greed of dowry and wealth, unemployment, disparity in education, joint family system, exchange marriages, early age marriages, birth of girl child, dual marriages, disparity in social status, external pressures, forced and pressurized marriages, spousal illegal relationships, unrealistic expectations, fraud in marriages ,drug abusing, age incompatibility, mental incompatibility, infertility, short-temperament or patience, lack of compromises or sacrifices, egoistical issues. With regard to solutions which may be impediments in stop breaking the legal agreement and relations between male and female like compromise and sacrifices, patience and endurance, empathetic way of analysis, develop feeling of "We" not "I", respect and honor, caring in every matter of life, no space for lie or mistrust, freedom of speech, egalitarian approach in decision making, sharing gifts and pleasures, caring about liking and disliking, pardon on mistakes, respect for family and relatives not by one part but from both the sides. Comprehensively, all relations can be secured 
Khaleek, S. Q., \& Hussain, A. (2015). Surge of Divorce in Lahore, its Exploring Factors and Possible Solutions, Pakistan. Advances in Social Sciences Research Journal, 2(5) 143-152

and saved if there is feelings, emotions, need and love exist towards both genders and if all these demand space than all in vain.

\section{References}

The Daily Times, June 23, 2008

Districts Courts Lahore 2014

Inam Rao (2011). Divorce rates climb, Pakistan Today. 